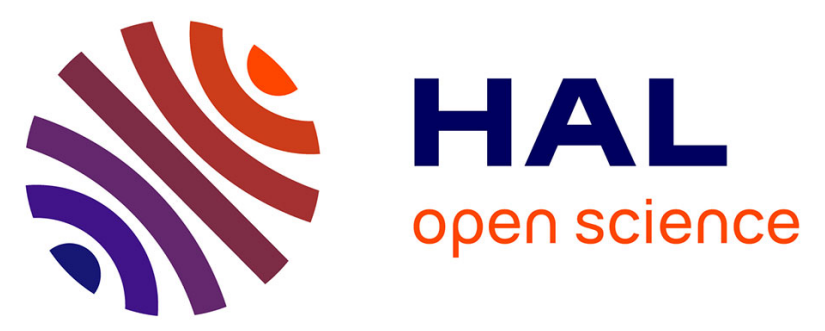

\title{
Collaborative Design of Warehousing 4.0 Using the Concept of Contradictions
}

Dmitry Kucharavy, David Damand, Marc Barth, Ridha Derrouiche

\section{To cite this version:}

Dmitry Kucharavy, David Damand, Marc Barth, Ridha Derrouiche. Collaborative Design of Warehousing 4.0 Using the Concept of Contradictions. 19th Working Conference on Virtual Enterprises (PRO-VE), Sep 2018, Cardiff, United Kingdom. pp.396-405, 10.1007/978-3-319-99127-6_34 . hal02191167

\section{HAL Id: hal-02191167 \\ https://hal.inria.fr/hal-02191167}

Submitted on 24 Jul 2019

HAL is a multi-disciplinary open access archive for the deposit and dissemination of scientific research documents, whether they are published or not. The documents may come from teaching and research institutions in France or abroad, or from public or private research centers.
L'archive ouverte pluridisciplinaire HAL, est destinée au dépôt et à la diffusion de documents scientifiques de niveau recherche, publiés ou non, émanant des établissements d'enseignement et de recherche français ou étrangers, des laboratoires publics ou privés. 


\title{
Collaborative Design of Warehousing 4.0 Using the Concept of Contradictions
}

\author{
Dmitry Kucharavy ${ }^{1}$, David Damand ${ }^{1}$, Marc Barth ${ }^{1}$ and Ridha Derrouiche ${ }^{1}$ \\ ${ }^{1}$ EM Strasbourg Business School, Université de Strasbourg \\ HuManiS (EA 7308) \\ 61 avenue de la Forêt-Noire, F-67085 Strasbourg Cedex, France \\ dzmitry.kucharavy@etu.unistra.fr
}

\begin{abstract}
The general context of this paper is the strategic planning of distribution centre warehouses. The idea is to anticipate changes in the warehouse based on objectives and issues generally linked to market (e.g.: electronic trade, etc.) and environmental developments (e.g.: last-mile logistics, etc.). Planning requires overcoming the consequences of the choices made as well as their interactions. To inform and justify projected technological choices, it is crucial to identify and understand design rules which are often contradictory. Problems arise out of contradictions! To support strategic planning, the decision-making aid proposed in this paper consists of extracting and formalising all problems in the form of contradictory design rules.
\end{abstract}

Keywords: Warehousing systems, Strategic planning, Technology forecasting, Evolution of warehousing, Cartography of contradictions.

\section{Introduction}

To a large extent, the logistics costs of warehouses are determined during the design phase [1]. As a general rule, based on a functional description, the warehouse design phase consists of choosing a layout and associated technologies of the four core activities (receiving, storage, order picking and shipping), as well as a planning mode for the operations related to these activities [2], [3]. Changes in this functional description are primarily correlated with the rapidly evolving market [4]. The emergence of new consumption patterns, such as e-commerce for example, is likely to impose the introduction of new dedicated storage technologies, involving substantial investment and high financial risks to boot.

As a result, it is imperative to plan and control the strategic evolution of logistic warehouses. Strategic planning decisions, generally characterised by a 10 to 15 year timeframe, relate to the determination of the general policies and plans for the use of the resources of the future warehouse [5].

In some cases, these evolutions can be promptly addressed via planned decisions; the activities associated with the decision are execution activities [6]. Conversely, when there are no decisions relating to the new situation, a problem solving activity is required. These unscheduled decisions are more difficult to examine as they involve a 
wide-ranging body of knowledge (endogenous and exogenous to the warehouse). This body of knowledge is often contradictory.

Research projects undertaken in warehousing design primarily focus on endogenous warehousing parameters [7], [8]. Few projects simultaneously factor in endogenous and exogenous parameters. The warehouse of the future depends on environmental developments. Market demands, limitations and trends bring about operational, technological and organisational innovations and changes [4]. This context raises two research questions. First question: what are the key characteristics for strategic decision-making in terms of warehousing design? Second question: how to define a systematic method for identifying key warehousing design parameters?

This paper proposes a contribution to the first question only. The expected contribution is the formalisation of a number of generic design rules (means/effect) using an adapted language [7]. The expected nature of design rules is contradiction.

The paper is structured as follows. Chapter 2 presents the theoretical framework. Chapter 3 presents the methodological framework to identify and extract generic design rules. Chapter 4 presents an industrial application by a 3PL logistics provider. Finally, chapter 5 concludes this paper and outlines research prospects.

\section{Literature Review - Theoretical Framework}

A warehouse can be represented as a storage tank [9]. It has a buffer function in light of the variability and uncertainty inherent in the supply chain. Its life cycle includes three major stages: design and construction; operation, development and reorganisation; decommissioning or reprocessing. To consider conceptual design on a 5 to 10 year timeframe in terms of organisational architecture and processes, a reliable vision of the demands, limitations and trends of the future warehouse is needed [4]. The strategic decision relating to warehouse evolution must take account of the dynamic changes of the activities and functions, as well as the specific characteristics of the system's life cycle [10].

Strategic decision-making in warehousing design is linked to the following generic questions:

- What are the achievable and unachievable performance levels?

- Is it necessary to modify the condition of the existing system?

- What is the effect of decision criteria on the new situation?

- What are the most significant decision criteria in terms of system performance?

- When decision criteria cannot be modified simultaneously, in what chronological order should these criteria be modified?

Etc.

The traditional approach in the design phase consists of inventing, creating possible alternatives from which to choose. The rational decision-making model [11], [12], is a 6-step process [13]: 1. define the problem; 2. identify decision criteria; 3 . weight the criteria; 4 . develop alternatives; 5 . assess alternatives (rule if criterion $=\ldots$ then alternative $=\ldots$ ); 6 . choose the best alternative. This model is a sequential and logical structuring of the information to be analysed [5], [14]. The multi-criteria 
approaches generally undertaken [6] help select the best solution or the optimal solution from a broad range of solutions, the YES-NO type alternative being one particular case as part of a more general case. When alternatives are incompatible with the decision criteria values, a position must be taken in relation to these contradictions.

This paper hypothesises that the problem solving process during the design phase involves the identification of one or more contradictions resulting from the new decision context (e.g. market developments). Consequently, contradictions are the expression of a problem by consequences of the choices made, but obviously at least two opposing consequences are required for a problem to arise. By expressing the cause-and-effect relationships between means and performance, the contradiction identification process reveals the rules used. This helps clarify conflict areas, but also and most importantly the reasons for projected technological choices.

To advance the decision-making process towards a choice of technological solution, literature proposes several technological forecasting methods. Initial significant research dates back to the early 20th century [15], [16], [17]. The primary purpose of these methods is to provide a consensual view of the future technological situation [18]. A review of scientific journals, institutional reports and publications [19], [20], [21] highlights methodological advances in terms of technological forecasting for socio-economic and technological levels, rather than for the technological level itself. The major improvements identified by the methods used to forecast technological changes relate to a combination of existing techniques and models, and the refinement of existing methods [22], [23]. The exponential increase in the number of publications, institutions and researchers involved in forecasting and the development of technological forecasting methods in the past five decades has yielded a multitude of techniques and methodologies [24].

After reviewing the current practice of long-term technological forecasting methods, these methods can be classified into four categories [25]:

(1) phenomenological models (for example time series data extrapolations, regressions),

(2) intuitive models (for example the Delphi method, structured and unstructured interviews),

(3) monitoring and mapping (for example by reviewing the literature and sources published, scenarios, mapping of existing information),

(4) and finally, the causal models used in this paper to analyse warehousing system evolution rules.

The next chapter describes the method based on causal models.

\section{Research Methodology}

The research-intervention method selected relies on the "Researching Future" method (technological forecasting method) [26], [27]. This method combines maps of contradictions [28] with S-curves of logistics functions [29], [30]. The research method follows the methodological triangulation principle. Triangulation is often 
used in management sciences. According to [31], [32], "triangulation should support a finding by demonstrating that independent measures of it agree with or, at least, do not contradict it". Denzin [33] highlighted three types of triangulation: the use of different data sources (time, space, persons); the use of different researchers; the simultaneous use of different methods.

To obtain the map of contradictions, the "Researching Future" method used in this paper connects the principles of the following methods:

- $\quad$ the "System Operator" model from the Theory of Inventive Problem Solving - TRIZ [34],

- the "Contradiction" model derived from TRIZ is developed to model networks of problems within OTSM-TRIZ [35],

- $\quad$ S-curves [30],

- $\quad$ technology substitution models are used to measure the time and capacity of evolution and substitution processes [36], [37],

- $\quad$ interpretation patterns of the knowledge obtained from the DITEK model [38].

The contradiction representation language is illustrated in Fig. 1a.

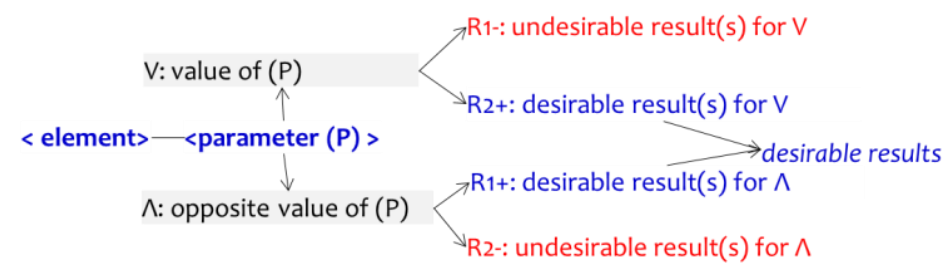

Fig. 1a. Contradiction description model.

An example of contradiction is described in Fig. 1b corresponding with the following interrogation:

In the $<$ distribution centre $>$ system, the trend $<$ significant flow heterogeneity $>$ encounters a barrier $<$ storage profitability $>$. 


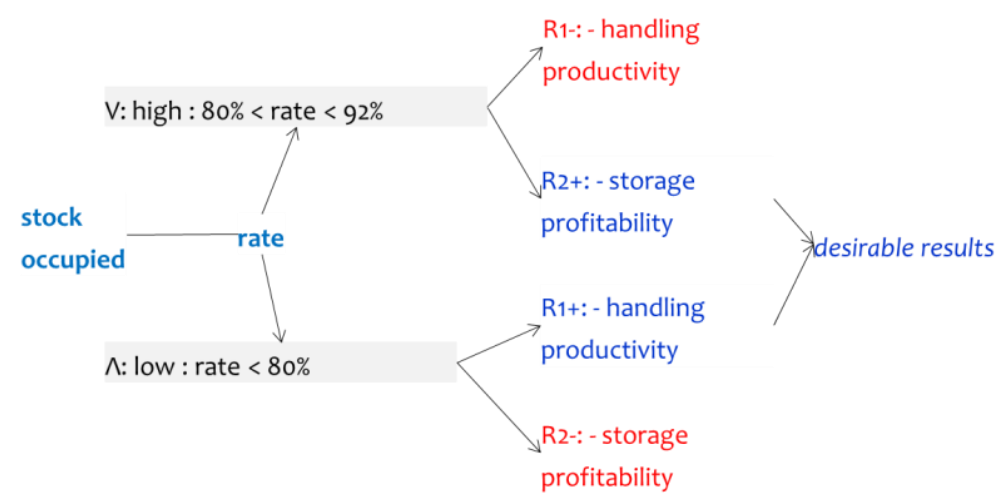

Fig. 2b. Example of contradiction : handling productivity = number of (parcels or pallets)/hour; storage profitability $=\left(\right.$ storage turnover $\left./ \mathrm{m}^{2}\right) / \operatorname{cost}$ per $\mathrm{m}^{2}$ of the storage surface area

The semantics used are as follows:

- Element - everything (tangible or intangible) used in a combination to form a whole or a unit,

- System - group of elements interacting with each other, linked and interdependent, performing a certain function as part of a super-system.

- $\quad$ Trend - change in a system characteristic over a long period.

- $\quad$ Barrier - limitation of resources (e.g., space, time, energy),

- Parameter - characteristic of an element which can be acted upon,

- Result - consequence of an action due to the value of a parameter (e.g. desired result); every indicator has a measurable value, measurement unit standard required to measure an indicator.

The following syntax is used:

Contradiction - model to describe a problem through the description of a conflict of interest. The contradiction model includes an element, a parameter, a parameter value and an opposing parameter value, desired results $(\mathrm{R} 1+, \mathrm{R} 2+)$ and unwanted results (R1-, R2-). Contradiction appears in the following case: when the evolution in the value of a parameter towards the R2+ desired leads to an unwanted R1-, and when the change in the opposing value of a parameter towards the $\mathrm{R} 1+$ desired leads to an unwanted R2-.

\section{Case Study}

Intervention research is conducted in a French 3PL. Their turnover in 2016 was $€ 2.045$ billion. The scope of the study consists of 25 warehouses. Customers are mainly from the agri-food, retail and healthcare industry. 
A working group was assembled. The group includes 6 individuals, respectively 3 experts in 3PL and 3 researchers. The group had 26 meetings of 4 working hours over a 12-month period. The project management method is applied in generic stages:

- identification of needs,

- $\quad$ study scope specification,

- identification of stakeholders,

- $\quad$ consolidation of principal expert questions,

- $\quad$ analysis accuracy definition,

- $\quad$ consolidation of the expression of expected results.

To define the scope of the warehousing system (WS), the primary function is formulated and specified: "Provide customers with the desired quantity of products within the desired deadline".

To comprehend significant changes in warehousing design and process, we collected chronological data on the surface area of the LP's warehouses $\left(\mathrm{m}^{2}\right)$. As the built-up surface and expected values are confidential information for the LP, no actual figure will be presented. The partial results of the study are presented in Fig. 2 and 3. The S-curves obtained help position the current WS in relation to its life cycle. Scurves are developed on the basis of 25 WSs spread over 13 countries.

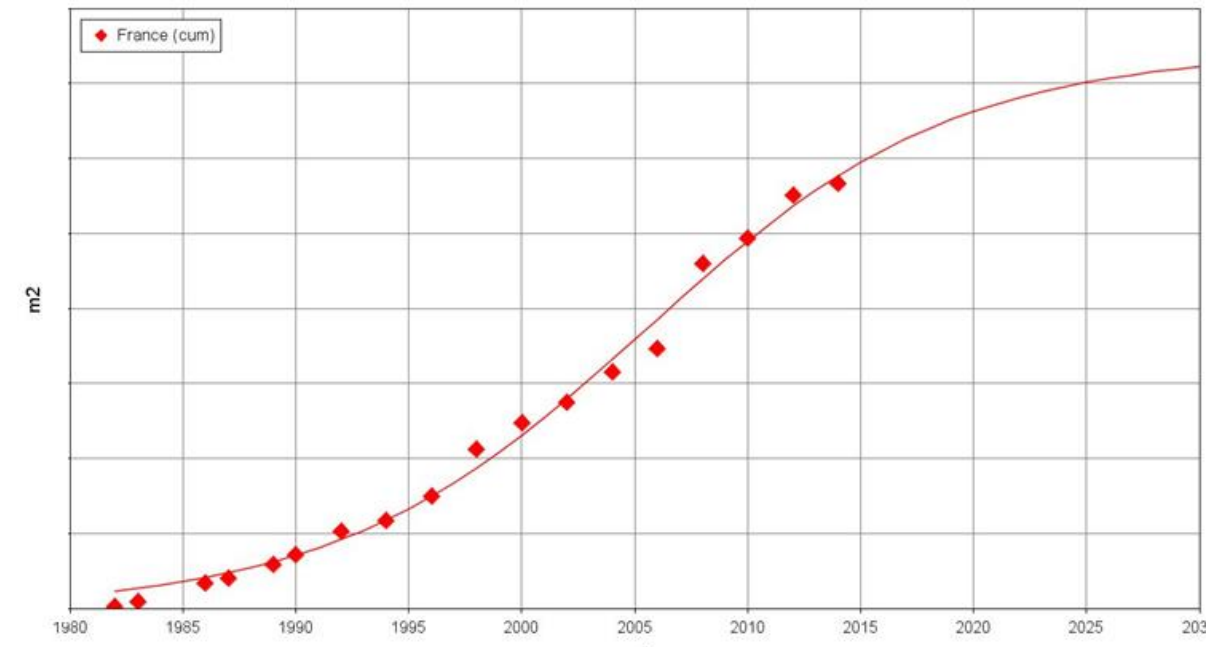

Fig. 2. Example of changes in the surface area of WSs built in France in $\mathrm{m}^{2}$ $(\mathrm{Tm}=2005.5 ; \Delta \mathrm{t}=30.1 ;$ Rsquare $=0.993)$

The increase in the surface area of existing WSs in France should stop by 2020 (Fig. 2). At global level, it is estimated that saturation will be reached by 2022. New warehousing technologies should drive revenue growth without increasing the surface area of WSs.

The major characteristics of these new technologies are justified by the WS's map of contradictions. Every contradiction is developed based on an interrogation, trend and barrier. 
When formulating contradictions, certain interrogations were excluded from the study as they were deemed irrelevant. Two new contradictions were identified. A number of interrogations were aggregated and represented by the same contradictions.

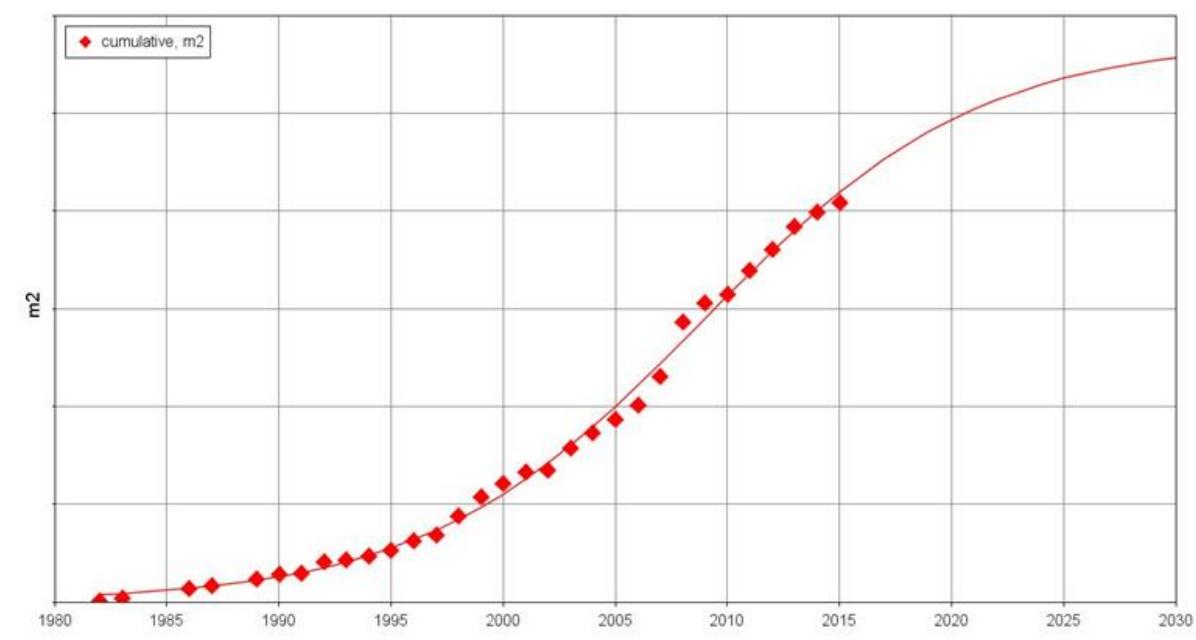

Fig. 3. Changes in the surface area of WSs built worldwide in $\mathrm{m}^{2}$ $(\mathrm{Tm}=2008.9 ; \Delta \mathrm{t}=27.2 ;$ Rsquare $=0.996)$

As a result of the work carried out by the working group, the outcome is characterised by: 21 trends, 48 drivers, 49 barriers and 281 desired results. To facilitate the connection of contradictions, the 281 results are classified into six indicator categories (Table 1). Fig. 4 presents a fragment of the map of the 58 resulting contradictions.

Table 1. Distribution of performance indicators and desired results by category.

\begin{tabular}{lcc}
\hline Category & $\begin{array}{c}\text { number of performance } \\
\text { indicators / category }\end{array}$ & $\begin{array}{c}\text { number of desired } \\
\text { results / category }\end{array}$ \\
\hline 1. Lead-time & 6 & 37 \\
2. Logistic cost & 35 & 115 \\
3. Investments & 15 & 43 \\
4. Delivery method & 8 & 33 \\
5. Productivity & 16 & 34 \\
6. Flexibility & 8 & 19 \\
\multicolumn{1}{c}{ TOTAL: } & $\mathbf{8 8}$ & $\mathbf{2 8 1}$ \\
\hline
\end{tabular}

To achieve a definitive description of the most significant contradictions (in terms of changes in the WSs), the direct links between the contradictions formulated must be examined. This activity is under review. 


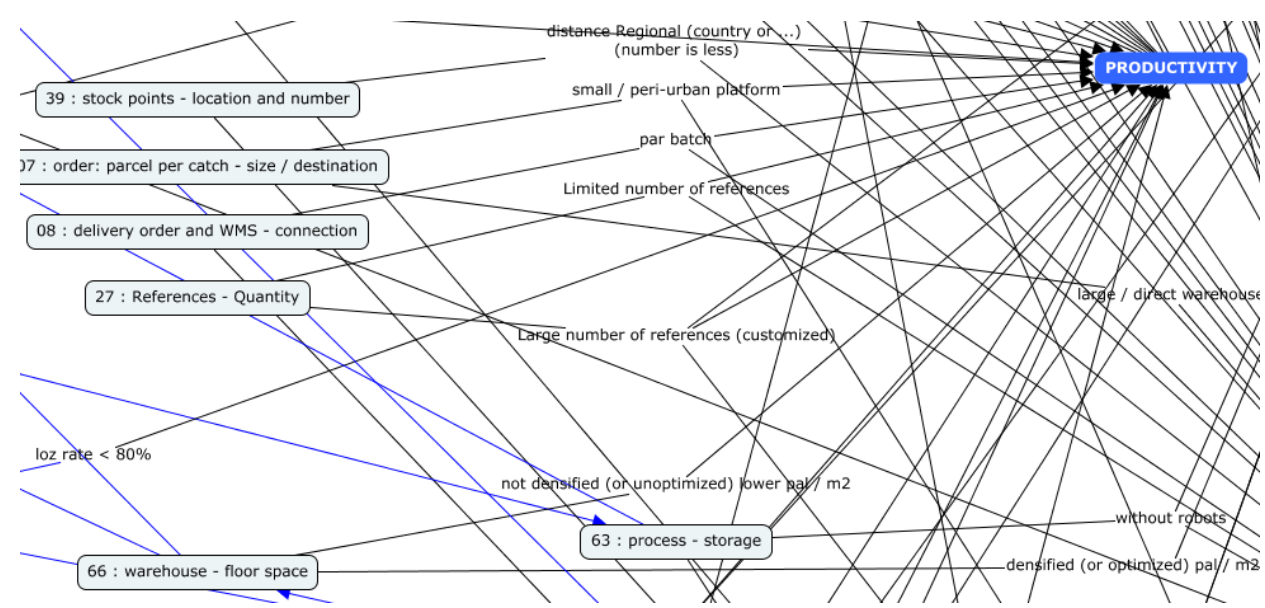

Fig. 4. Extract from the map of 58 contradictions

The map of contradictions represents the conflicts of interest between seven major players (Fig. 5). The number of most significant contradictions concerns the logistics provider and the industrial producer, who are therefore the key players in the change process.

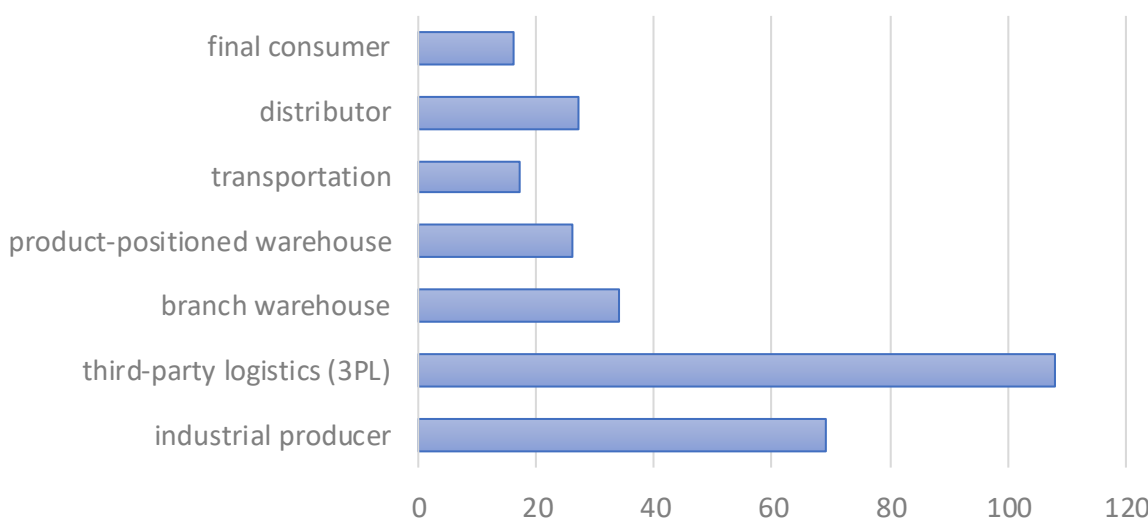

Fig. 5. Number of connections classified by stakeholder

\section{Discussions and Prospects}

The issue dealt with in this paper is as follows: "what are the key characteristics for strategic decision-making in terms of warehousing design?". The result is the definition of a map of ware-housing system contradictions. Problems are represented in the form of contradictions for identifying major future WS characteristics. The 
result achieved is described by a map of 58 contradictions. These contradictions are obtained by linking 281 desired results (e.g. location of the ware-house) with 88 performance indicators (e.g. delivery times, etc.) classified into 6 categories (e.g. logistics cost, etc.). These contradictions concern 7 stakeholders (e.g. end user, distributor, etc.). The concept of contradiction is pertinent for initiating issues pertaining to the strategic evolution of WSs.

The results obtained only allow for partial generalisation, as the scope of application is characterised by $25 \mathrm{WSs}$ from the agri-food, retail and healthcare industry. The prospects of this study are the prioritisation of contradictions and the development of a systematic method designed to identify contradictions.

\section{Acknowledgments.}

This study was funded by FM Logistic Corporate SAS. We wish to thank the members of FM Logistic who generously devoted time to this study.

\section{References}

1. Roveillo, G, Fulconis F., Paché G. : "Vers une dilution des frontières de l'organisation: le prestataire de services logistiques (PSL) comme pilote aux interfaces." Logistique \& Management 20.2, 7-20 (2012)

2. Gu, J., Goetschalckx, M., McGinnis, L.F.: Research on warehouse operation: A comprehensive review. Eur. J. Oper. Res. 177, 1-21 (2007).

3. Rouwenhorst, B., Reuter, B., Stockrahm, V., Houtum, G.J. van, Mantel, R.J., Zijm, W.H.M.: Warehouse design and control: Framework and literature review. Eur. J. Oper. Res. 122, 515-533 (2000).

4. De Koster, R.B.M., Johnson, A.L., Roy, D.: Warehouse design and management. Int. J. Prod. Res. 55, 6327-6330 (2017).

5. Harrison, E.F.: The managerial decision-making process. Houghton Mifflin Boston, MA (1995).

6. Roy, B.: Méthodologie Multicritère d'Aide à la Décision. Economica, Paris, France (1985).

7. Chen, I.J., Paulraj, A.: Towards a theory of supply chain management: The constructs and measurements. J. Oper. Manag. 22, 119-150 (2004).

8. Schnetzler, M.J., Sennheiser, A., Schönsleben, P.: A decomposition-based approach for the development of a supply chain strategy. Int. J. Prod. Econ. 105, 21-42 (2007).

9. Fender, M., Pimor, Y.: Logistique \& Supply Chain. Dunod, Paris, France (2013).

10. Andersson, J.K., Wemnér, T.: A Strategic Decision-Making Model for Supply Chain - A void to be Filled, (2008).

11. Simon, H.A.: A behavioral model of rational choice. Q. J. Econ. 69, 99-118 (1955).

12. Hastie, R., Dawes, R.M.: Rational choice in an uncertain world: The psychology of judgment and decision making. Sage (2010).

13. Robbins, S.P., Judge, T., Tran, V.: Comportements organisationnels. Pearson Education France (2014).

14. Robbins, S.P., Judge, T., Breward, K.: Essentials of organizational behavior. Prentice Hall Upper Saddle River (2003).

15. Ayres, R.U.: Technological Forecasting and Long-Range Planning. McGraw-Hill book Company (1969). 
16. Linstone, H.A., Turoff, M.: Delphi: A brief look backward and forward. Technol. Forecast. Soc. Change. 78, 1712-1719 (2011).

17. Martino, J.P.: Technological Forecasting for Decision Making. Elsevier Publishing Company, New York (1972).

18. Kostoff, R.N., Schaller, R.R.: Science and Technology Roadmaps. IEEE Trans. Eng. Manag. 48, 132-143 (2001).

19. Roper, T.A., Cunningham, S.W., Porter, A.L., Mason, T.W., Rossini, F.A., Banks, J.: Forecasting and Management of Technology. John Wiley \& Sons Ltd (2011).

20. Armstrong, J.S.: Principles of Forecasting: A Handbook for Researchers and Practitioner. Kluwer Academic Publishers, Boston / Dordrecht / London (2002).

21. Grübler, A.: Technology and Global Change. International Institute of Applied System Analysis, Cambridge (2003).

22. Glenn, J.C., Gordon, T.J.: Futures Research Methodology. Version 2.0, http://www.millennium-project.org/millennium/FRM-v2.html, (2003).

23. Miranda, L.C.M., Lima, C.A.S., Piedade, R.: On trends and rhythms in scientific and technological knowledge evolution: a quantitative analysis. Int. J. Technol. Intell. Plan. 6, 76-109 (2010).

24. Slupinski, M.: Technology Forecasting - State of the Art Update / Deliverable 2.3 FORMAT Project. , Milan, Italy (2013).

25. Cascini, G., Becattini, N., Kaikov, I., Koziolek, S., Kucharavy, D., Nikulin, C., Petrali, P., Slupinski, M., Rabie, M., Balachandar, R., Ruggeri, L., Vanherck, K.: FORMAT - Building an original methodology for Technology Forecasting through researchers exchanges between industry and academia. Procedia Eng. 131, 1084-1093 (2015).

26. Kucharavy, D., De Guio, R.: Technological Forecasting and Assessment of Barriers for Emerging Technologies, http://hal.archives-ouvertes.fr/hal-00282751/en/, (2008).

27. Kucharavy, D.: Combination of Contradictions Based approach and Logistic Curves models for Strategic Technological Forecasting. In: Global TRIZ Conference 2013 in Korea., Seoul, Korea (2013).

28. Kucharavy, D., De Guio, R., Gautier, L., Marrony, M.: Problem Mapping for the Assessment of Technological Barriers in the Framework of Innovative Design. In: 16th International Conference on Engineering Design, ICED'07. Ecole Centrale Paris, Paris, France (2007).

29. Modis, T.: Technological Substitutions in the Computer Industry. Technol. Forecast. Soc. Change. 43, 157-167 (1993).

30. Modis, T.: Natural Laws in the Service of the Decision Maker: How to Use Science-Based Methodologies to See More Clearly further into the Future. Growth Dynamics (2013).

31. Miles, M.B., Huberman, A.M.: Analyse des données qualitatives. De Boeck Supérieur (2003).

32. Rothbauer, P.: Triangulation. SAGE Encycl. Qual. Res. methods. 1, 892-894 (2008).

33. Denzin, N.K.: The research act: A theoretical orientation to sociological methods, (1978).

34. Altshuller, G.S., Williams, A.: Creativity as an Exact Science: The Theory of the Solution of Inventive Problems. Gordon and Breach Science Publishers (1984).

35. Khomenko, N., Yoon, H.: OTSM-TRIZ as a Response to the Request from the Specialized and Interdisciplinary Problem Situations. In: Korea TRIZCON 2010. p. 16 (2010).

36. Marchetti, C., Nakicenovic, N.: The dynamics of energy systems and the logistics substitution model. Int. Inst. Appl. Syst. Anal. Res. Rep. 79-13, 71 (1979).

37. Modis, T.: Predictions - 10 Years Later. Growth Dynamics, Geneva, Switzerland (2002).

38. Grundstein, M.: Three Postulates That Change Knowledge Management Paradigm. In: Hou, H.-T. (ed.) New research on knowledge management models and methods. pp. 1-22. InTech (2011). 